\title{
THE EFFECTS OF DIFFERENT NITROGEN APPLICATION AND SEEDING RATES ON THE YIELD AND GROWTH TRAITS OF DIRECT SEEDED RICE (ORYZA SATIVA L.) USING CORRELATION ANALYSIS
}

\author{
TANG, J. C. ${ }^{1 \#}-$ CHEN, Q. H. ${ }^{1 \#}-$ HAO, R. Q. ${ }^{1 \#}-$ LI, Z. X. ${ }^{1}-$ LU, B. L. ${ }^{1,2,3 *}$ \\ ${ }^{1}$ Hubei Collaborative Innovation Center for Grain Industry, Agricultural college, Yangtze \\ University, Jingzhou Hubei 434025, China \\ e-mail:201872415@yangtzeu.edu.cn (Tang,J.C.); kawhichen@yeah.net (Chen, Q.H.); \\ rachel15337179705@163.com (Hao,R.Q.); 201872409@yangtzeu.edu.cn (Li, Z.X.) \\ ${ }^{2}$ Engineering Research Center of Ecology and Agricultural Use of Wetland, Ministry of \\ Education, Jingzhou Hubei 434025, China
}

${ }^{3}$ Hubei Provincial Key Laboratory of Waterlogged Disasters and Agricultural Use of Wetland, Jingzhou Hubei 434025, China

${ }^{\#}$ These authors contributed equally to this work.

${ }^{*}$ Corresponding author

e-mail:blin9921@sina.com

(Received $26^{\text {th }}$ Sep 2020; accepted $21^{\text {st }}$ Dec 2020)

\begin{abstract}
Optimization of nitrogen $(\mathrm{N})$ application rate and seeding rates to coordinate the balanced development of crop growth and yield is important for the efficient use of resources and the cultivation of high-quality and high-yield crops. In this study, four levels of $\mathrm{N}$ application rates $\left(\mathrm{N} 00 \mathrm{~kg} \mathrm{ha}^{-1}\right.$, $\mathrm{N} 1150 \mathrm{~kg} \mathrm{ha}^{-1}, \mathrm{~N} 2190 \mathrm{~kg} \mathrm{ha}^{-1}$, and N3 $240 \mathrm{~kg} \mathrm{ha}^{-1}$ ) and three direct seeding rates (D1 $22.22 \mathrm{~kg} \mathrm{ha}^{-1}, \mathrm{D} 2$ $25.00 \mathrm{~kg} \mathrm{ha}^{-1}$, and D3 $28.57 \mathrm{~kg} \mathrm{ha}^{-1}$ ) were used to explore their effects on the yield and growth characteristics of direct seeded rice (Oryza sativa L.) in China. Canonical correlation analysis showed that the soil-plant analyses development (SPAD) value, leaf area index (LAI), and plant height were closely related to grain yield, spikelet number per panicle, and seed setting rate, and the increase in the SPAD value may have caused the increase in the number of effective panicles and the decrease in 1000-grain weight. Gray correlation analysis showed that plant height and leaf area index were essential indices that affected grain yield. For increased grain yield, medium N and medium density (N2D2) were suitable for hybrid rice, whereas high $\mathrm{N}$ and high density (N3D3) were suitable for conventional rice. Plant height and leaf area index may be used as important growth indices to control yield.
\end{abstract}

Keywords: nitrogen fertilizer, sowing rate, mechanical seeding, canonical correlation analysis, Gray correlation analysis, grain yield, growth parameter

\section{Introduction}

Rice feeds more than half of the world's population, and the main areas for its cultivation and consumption are in Asia (Kumar and Ladha, 2011; Abid et al., 2015). In China, direct seeding is a method of rice cultivation that solves the problems of labor shortage and low profits (Chen et al., 2009; Liu et al., 2015). Reasonable nitrogen application rates and seeding rates promote the growth and grain yield of direct-seeded rice, reducing resource waste and environmental pollution (Aslam et al., 2002; Liang et al., 2013).

Nitrogen $(\mathrm{N})$, one of the basic nutrient elements required for plant growth, is a key limiting factor for crop growth and production (Tang et al., 2019). In developing countries, 
soil fertility is the most important factor that limits crop yields, half of the increase for which is due to the use of inorganic fertilizers (Rodríguez et al., 2014; Aleminew et al., 2020). The amount of $\mathrm{N}$ fertilizer applied should be determined based on local soil conditions and the characteristics of specific rice varieties, rather than simply increasing the amount of $\mathrm{N}$ fertilizer to achieve the goal of higher yields (Rezaei et al., 2009). Excessive application of $\mathrm{N}$ fertilizer can lead to a decline in $\mathrm{N}$ use efficiency and yield (Peng et al., 2007). It has been reported that the yield components and yield of rice under medium $\mathrm{N}$ levels $\left(210 \mathrm{~kg} \mathrm{ha}^{-1}, 260 \mathrm{~kg} \mathrm{ha}^{-1}\right.$, and $\left.315 \mathrm{~kg} \mathrm{ha}^{-1}\right)$ are significantly higher than under low (160 kg ha ${ }^{-1}$ ) and high (420 $\left.\mathrm{kg} \mathrm{ha}^{-1}\right) \mathrm{N}$ levels (Li et al., 2020). Studies have also shown that the best $\mathrm{N}$ application rate in paddy fields is $60 \mathrm{~kg} \mathrm{ha}^{-1}$, and the yield of rice will not increase if the $\mathrm{N}$ application rate exceeds it (Rezaei et al., 2009). In addition to the $\mathrm{N}$ application rate, the seeding rate of rice also strongly affects grain yield. Plant population density is the primary factor that affects the occurrence of tillering (Schnier et al., 1990). The lower the seeding density, the taller the plant, the greater the tillering efficiency, the lower the sterility, and the higher the grain yield (Thapa et al., 2019). However, excessive plant population density can lead to greater plant height and weaker stalks, increasing the potential for losses due to lodging and disease (Dofing and Knight, 1994). When previous studies are summarized, it becomes clear that suitable $\mathrm{N}$ application rates and seeding rates differ markedly among regions, and further systematic study is needed. It is also clear that crop growth traits are closely related to yield. However, most research on the correlation between crop growth indices and yield or yield components has considered the relationships between individual indices in isolation, ignoring the relationships between variable groups. The results of such analyses may be incomplete or superficial (Liu et al., 2014; Li et al., 2019a).

In this study, hybrid rice and conventional rice were used as experimental crops. We tested multiple $\mathrm{N}$ application rates and seeding rates and used canonical correlation analysis and grey correlation analysis to assess the effects of growth characteristics on rice yield. We identified the optimal $\mathrm{N}$ application and sowing rates for hybrid and conventional rice, and identified growth characteristics that were most closely related to yield. The findings of this research provide a scientific basis and theoretical guidance for efficient crop planting.

\section{Materials and Methods}

\section{Experimental materials}

The rice varieties C Liangyouhuazhan (hybrid) and Huanghuazhan (conventional) were provided by Golden Nonghua Seed Industry Co., Ltd. (Beijing, China) and Hubei Seed Group Co., Ltd. (Wuhan, China), respectively.

\section{Field site and experimental design}

The experiments were conducted from 2018 to 2019 in the Agricultural Science and Technology Industrial Park of Yangtze University, Huazhong Agricultural High-Tech Industrial Development Zone, Jingzhou City, Hubei Province, China $\left(30^{\circ} 220^{\prime} \mathrm{N}\right.$, $\left.112^{\circ} 40^{\prime} \mathrm{E}\right)$. The test area was located in the Jianghan Plain in the middle reaches of the Yangtze River. It has a subtropical monsoon climate with an average annual sunshine duration of approximately 2000 hours and a total annual solar radiation value of approximately $460-480$ kilojoule $\mathrm{cm}^{-2}$. The average annual precipitation is 
1100-1300 mm, and the precipitation from April to September accounts for $70 \%$ of the total annual precipitation. The soil type was a light loam (Kakingski soil texture classification system), and the basic physical and chemical properties of the soil in the 0-20 cm depth were as follows: a $\mathrm{pH}$ of 7.74, an organic matter content of $22.18 \mathrm{~g} \mathrm{~kg}^{-1}$, an alkaline $\mathrm{N}$ content of $73.63 \mathrm{mg} \mathrm{kg}^{-1}$, an available phosphorus content of $28.55 \mathrm{mg} \mathrm{kg}^{-1}$, and a fast-acting potassium content of $186.40 \mathrm{mg} \mathrm{kg}^{-1}$.

Seeds were sown on June $1^{\text {st }}$, and the harvest date was October $2^{\text {nd }}$. The experiment used a split-plot design. There were four $\mathrm{N}$ fertilizer application rates (N3 $240 \mathrm{~kg} \mathrm{ha}^{-1}$, N2 $195 \mathrm{~kg} \mathrm{ha}^{-1}$, N1 $150 \mathrm{~kg} \mathrm{ha}^{-1}$ and N0 $0 \mathrm{~kg} \mathrm{ha}^{-1}$ ) and three sowing rates (D3 $28.57 \mathrm{~kg} \mathrm{ha}^{-1}$, D2 $25.00 \mathrm{~kg} \mathrm{ha}^{-1}$, and D1 $22.22 \mathrm{~kg} \mathrm{ha}^{-1}$ ). The $\mathrm{N}$ application rate was the main plot factor and sowing rate was the subplot factor. Each treatment was replicated three times for each rice variety, the area of each plot was $30 \mathrm{~m}^{2}$, and the total number of plots was 72. Details of $\mathrm{N}$ fertilizer and seeding management are shown in Table 1. The ratio of $\mathrm{N}, \mathrm{P}_{2} \mathrm{O}_{5}$, and $\mathrm{K}_{2} \mathrm{O}$ in the compound fertilizer was 15:15:15, and $46 \%$ of the applied $\mathrm{N}$ was in the form of urea. Compound fertilizer was applied as a base fertilizer at sowing, urea was applied at the tillering stage, and compound fertilizer was applied at the panicle initiation stage. The ratio of $\mathrm{N}$ applied for the three periods was 5:3:2. The content of $\mathrm{P}_{2} \mathrm{O}_{5}$ and $\mathrm{K}_{2} \mathrm{O}$ in each treatment was adjusted to $168 \mathrm{~kg} \mathrm{ha}^{-1}$ using calcium superphosphate $\left(16 \% \mathrm{P}_{2} \mathrm{O}_{5}\right)$ and potassium chloride $\left(60 \% \mathrm{~K}_{2} \mathrm{O}\right)$. Sowing was performed using mechanical direct seeding at three direct seeding densities (seeding rates) of $25 \mathrm{~cm} \times 14 \mathrm{~cm}\left(28.57 \mathrm{~kg} \mathrm{ha}^{-1}\right), 25 \mathrm{~cm} \times 16 \mathrm{~cm}\left(25.00 \mathrm{~kg} \mathrm{ha}^{-1}\right)$, and $25 \mathrm{~cm} \times 18 \mathrm{~cm}$ $\left(22.22 \mathrm{~kg} \mathrm{ha}^{-1}\right)$. Other management practices, such as disease and pest control, were performed according to local routine management. For example, the pretilachlor was applied 24 hours after rice seeding; the validamycin was used to control rice sheath blight from June to July; the flubendiamide was used to control rice borer (Cnaphalocrocis medinalis) in August.

Table 1. Nfertilizer and seeding management used in this study

\begin{tabular}{c|c|c|c|c|c}
\hline Treatment & $\begin{array}{c}\text { During sowing } \\
(\mathrm{N} \text { application, kg ha- } \\
1)\end{array}$ & $\begin{array}{c}\text { At the tillering } \\
\text { stage } \\
\text { (N application, kg } \\
\left.\text { ha }^{-1}\right)\end{array}$ & $\begin{array}{c}\text { During panicle } \\
\text { initiation stage } \\
\left(\mathrm{N} \text { application, } \mathrm{kg} \mathrm{ha}^{-}\right. \\
1)\end{array}$ & $\begin{array}{c}\text { Total N } \\
\text { application } \\
\left(\mathrm{kg} \mathrm{ha}^{-1}\right)\end{array}$ & $\begin{array}{c}\text { Seeding rate } \\
\left(\mathrm{kg} \mathrm{ha}^{-1}\right)\end{array}$ \\
\hline N3D3 & 120.00 & 72.00 & 48.00 & 240.00 & 28.57 \\
N3D2 & 120.00 & 72.00 & 48.00 & 240.00 & 25.00 \\
N3D1 & 120.00 & 72.00 & 48.00 & 240.00 & 22.22 \\
N2D3 & 97.50 & 58.50 & 39.00 & 195.00 & 28.57 \\
N2D2 & 97.50 & 58.50 & 39.00 & 195.00 & 25.00 \\
N2D1 & 97.50 & 58.50 & 39.00 & 195.00 & 22.22 \\
N1D3 & 75.00 & 45.00 & 30.00 & 150.00 & 28.57 \\
N1D2 & 75.00 & 45.00 & 30.00 & 150.00 & 25.00 \\
N1D1 & 75.00 & 45.00 & 30.00 & 150.00 & 22.22 \\
N0D3 & 0.00 & 0.00 & 0.00 & 0.00 & 28.57 \\
N0D2 & 0.00 & 0.00 & 0.00 & 0.00 & 25.00 \\
N0D1 & 0.00 & 0.00 & 0.00 & 0.00 & 22.22 \\
\hline
\end{tabular}

\section{Measurement indices}

SPAD value, leaf area index (LAI), dry matter accumulation, and plant height were assessed at the heading stage ( $80 \%$ of panicle emerged), and the largest tiller number of 
rice plants at the tillering stage was recorded. An area of $0.5 \mathrm{~m}^{2}$ was selected from each plot for the measurement of these growth characteristics. A SPAD-502 Plus chlorophyll analyzer (Konica Minolta, Japan) was used to measure the first complete leaf on the main stem, and the average of the upper third, middle third, and lower third of the leaf was taken as the SPAD value for the plant. Leaf area was measured using Image $\mathbf{J} 1.51 \mathrm{j} 8$ (National Institutes of Health, USA). Plants were selected for measurement of plant height, killed at a temperature of $105^{\circ} \mathrm{C}$, dried to constant weight at $80^{\circ} \mathrm{C}$, and weighed.

Yield and yield components were assessed after the maturation (95\% of rice husk were yellow) of the rice plants. An area of $5 \mathrm{~m}^{2}$ was selected from the central part of each plot for yield measurement. Ten rice plants were selected to investigate the average effective panicle number. Simultaneously, five plants were randomly selected for measurement of the number of grains per ear, the seed setting rate, and the 1000-grain weight.

\section{Correlation analyses}

Canonical correlation analysis is a multivariate mathematical statistical analysis method for studying the relationship between two groups of variables (Hardoon et al., 2004). Its purpose is to seek linear combinations of two separate sets of variables, such that the correlation between the two sets of variables is maximized. In this study, SPAD $\left(\mathrm{x}_{1}\right)$, LAI $\left(\mathrm{x}_{2}\right)$, dry matter accumulation $\left(\mathrm{x}_{3}\right)$, number of tillers $\left(\mathrm{x}_{4}\right)$, and plant height $\left(\mathrm{x}_{5}\right)$ were regarded as one set of variables. Grain yield $\left(\mathrm{y}_{1}\right)$, effective panicle number $\left(\mathrm{y}_{2}\right)$,

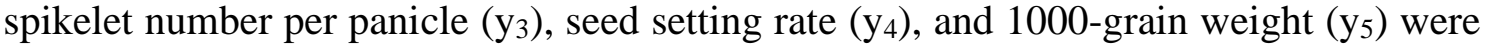
regarded as another set of variables, and canonical correlation analysis was performed between the two variable sets.

Gray correlation analysis (Peng and Zhang, 2010) was used to assess the correlation between individual growth characteristics (SPAD, LAI, dry matter accumulation, number of tillers, and plant height) and the reference series (yield). The greater the degree of correlation, the closer the changes between the growth characteristics and yield, and the closer their relationship. Yield $\left(\mathrm{Y}_{\mathrm{j}}\right)$ was set as the reference series, and the growth characteristic parameters were set as the comparison series $\left(\mathrm{X}_{\mathrm{i}}\right)$. The correlation coefficient between growth parameters $\left(\mathrm{X}_{\mathrm{i}}\right)$ and yield $\left(\mathrm{Y}_{\mathrm{j}}\right)$ and the degree of correlation of each factor were:

Correlation coefficient:

$$
\xi_{i}(\mathrm{k})=\frac{\min _{i} \min _{k}\left|Y_{j}(k)-X_{i}(k)\right|+\zeta_{i}^{\max } \max _{k}\left|Y_{j}(k)-X_{i}(k)\right|}{\left|Y_{j}(k)-X_{i}(k)\right|+\zeta_{i}^{\max } \max _{k}\left|Y_{j}(k)-X_{i}(k)\right|}
$$

Degree of correlation:

$$
r_{i}=\frac{1}{n} \sum_{\mathrm{k}=1}^{\mathrm{n}} \xi_{i}(k)
$$

In this formula (Eq.1), $\xi_{i}(\mathrm{k})$ is the correlation coefficient between $\mathrm{X}_{\mathrm{i}}$ and $\mathrm{Y}_{\mathrm{j}}$ at the point $\mathrm{K}, \zeta$ is the resolution coefficient of gray correlation $(\zeta=0.5)$; $\underset{i}{\min \min }\left|Y_{j}(k)-X_{i}(k)\right|$ is the absolute value of the second-level minimum difference, and $\max _{i} \max _{k}\left|Y_{j}(k)-X_{i}(k)\right|$ is the absolute value of the second-level maximum difference. The correlation degree between the comparison series and the reference series 
is determined according to the degree of correlation $r_{i}$ (Eq.2) to determine the importance of the comparison sequence to the reference sequence.

\section{Statistical analysis}

The data were analyzed and plotted using Data Processing System 7.05 (Qiyi Tang, China) and ORIGIN 2019 (OriginLab Corp., Northampton, MA, USA), respectively. Following a two-way ANOVA, treatment means were compared using the least significant difference (LSD) test at a $p \leq 0.05$ level of significance.

\section{Results \\ Effect of $N$ fertilizer application rate and seeding rates on hybrid rice yield and its components}

Hybrid rice yield and yield components under different $\mathrm{N}$ fertilizer rates and seeding rates are summarized in Table 2. Grain yield of each treatment increased initially and then decreased as $\mathrm{N}$ fertilizer and seeding rates were increased in 2018 and 2019. Grain yield was significantly higher in the $\mathrm{N} 2$ treatment than in the N1, N3, and N0 treatments by $6.58-67.15 \%$ in 2018 and $8.70-60.00 \%$ in 2019. There were no significant yield differences between the $\mathrm{N} 1$ and $\mathrm{N} 3$ treatments in either year. Grain yield of the D2 treatment was significantly higher than that of the D3 and D1 treatments by $4.90 \%$ and $11.01 \%$, respectively, in 2018 and by $3.48 \%$ and $6.15 \%$, respectively, in 2019 . Yield was significantly higher in the D3 treatment than in the D1 treatment by $5.82 \%$ in 2018 and by $2.58 \%$ in 2019 . Grain yield of the N1D2 and N2D2 treatments was higher than that of other $\mathrm{N}$ application and seeding rate combinations in 2018, and grain yield of the N2D2 treatment was higher than that of other combinations in 2019.

The effective panicle number and spikelet number per panicle of hybrid rice increased in response to $\mathrm{N}$ fertilization, but seed setting rate and 1000-grain weight decreased. The effective panicle number in the N2 treatment was significantly higher than in the N3, N1, and N0 treatments by $7.07 \%, 19.84 \%$, and $43.09 \%$, respectively. The spikelet number per panicle in the $\mathrm{N} 2$ treatment was significantly higher than in the $\mathrm{N} 1$ and $\mathrm{N} 0$ treatments by $3.60 \%$ and $2.92 \%$, respectively, and lower than in the N3 treatment by $16.51 \%$. The higher the seeding rate, the higher the effective panicle number but the lower the number of spikelets per panicle and the seed setting rate. The 1000-grain weight of the D2 treatment was higher than that of the D1 and D3 treatments by $0.12 \%$ and $1.37 \%$, respectively. Other yield components of the D2 treatment were in the middle of the three seeding rates. Compared with other $\mathrm{N}$ application and seeding rate combinations, the best yield performance of the N2D2 treatment may have been due to its high effective panicle number and the consistent responses of the other yield components.

\section{Effect of $N$ fertilizer application rate and seeding rates on conventional rice yield and its components}

The yield and yield components of conventional rice under different $\mathrm{N}$ fertilizer and seeding rates are summarized in Table 3. Grain yield of each treatment increased as $\mathrm{N}$ fertilizer and seeding rates were increased in 2018 and 2019. Grain yield was significantly higher in the $\mathrm{N} 3$ treatment than in the N2, N1, and N0 treatments by $9.88-81.04 \%$ (2018) and 5.03-51.31\% (2019). There were no significant differences between the N1 and N2 treatments in either year. Grain yield was significantly higher in the D3 treatment than in 
the D2 and D1 treatments by $4.49 \%$ and $7.27 \%$ in 2018 and by $4.17 \%$ and $4.66 \%$ in 2019 . There were no significant differences between the D1 and D2 treatments in either year. Grain yield of the N3D2 treatment was higher than that of other N application and seeding rate combinations in 2018, and grain yield of the N3D3 treatment was higher than that of other combinations in 2019.

Table 2. Hybrid rice yield and yield components under different $N$ fertilizer application rates and seeding rates

\begin{tabular}{|c|c|c|c|c|c|c|}
\hline \multirow{2}{*}{ Treatment } & \multirow{2}{*}{\begin{tabular}{|c|} 
Number of \\
effective panicles \\
$\left(10^{4} \mathrm{ha}^{-1}\right)$
\end{tabular}} & \multirow{2}{*}{$\begin{array}{l}\text { Number of } \\
\text { spikelets per } \\
\text { panicle }\end{array}$} & \multirow{2}{*}{$\begin{array}{l}\text { Seed setting } \\
\quad \text { rate }(\%)\end{array}$} & \multirow{2}{*}{$\begin{array}{l}1000 \text {-grain } \\
\text { weight }(\mathrm{g})\end{array}$} & \multicolumn{2}{|c|}{ Grain yield $\left(\mathrm{kg} \mathrm{ha}^{-1}\right)$} \\
\hline & & & & & 2018 & 2019 \\
\hline \multicolumn{7}{|c|}{ Treatment of $\mathrm{N}$ application rate } \\
\hline N3 & $347.45 \pm 7.76 b$ & $182.41 \pm 2.98 \mathrm{a}$ & $75.10 \pm 0.27 \mathrm{~d}$ & $23.99 \pm 0.11 \mathrm{c}$ & $10.76 \pm 0.22 b$ & $11.04 \pm 0.19 b$ \\
\hline $\mathrm{N} 2$ & $372.03 \pm 8.90 \mathrm{a}$ & $175.84 \pm 2.74 b$ & $78.67 \pm 0.26 \mathrm{c}$ & $24.20 \pm 0.15 b$ & $11.50 \pm 0.38 \mathrm{a}$ & $12.00 \pm 0.06 \mathrm{a}$ \\
\hline N1 & $310.43 \pm 10.51 \mathrm{c}$ & $170.85 \pm 2.05 \mathrm{c}$ & $3 \pm 0.15 b$ & $24.52 \pm 0.04 \mathrm{a}$ & $10.79 \pm 0.20 \mathrm{~b}$ & $10.95 \pm 0.19 b$ \\
\hline & $260.00 \pm 1.07 \mathrm{~d}$ & $150.92 \pm 1.65 \mathrm{~d}$ & $84.66 \pm 0.05 \mathrm{a}$ & $24.61=$ & $6.88 \pm 0.39 c$ & $7.50 \pm 0.04 \mathrm{c}$ \\
\hline \multicolumn{7}{|c|}{ Treatment of density } \\
\hline D3 & $335.40 \pm 7$ & $166.48 \pm 1.08 \mathrm{c}$ & & & $10.00 \pm 0$ & 10.34 \\
\hline D2 & $331.24 \pm 7.39 \mathrm{a}$ & $170.36 \pm 2.38 b$ & $0.20 \mathrm{~b}$ & $=0.08 \mathrm{a}$ & $10.49 \pm 0.09 a$ & $10.70 \pm 0.10 \mathrm{a}$ \\
\hline & $300.79 \pm 2.26 b$ & $173.18 \pm 2.83 \mathrm{a}$ & $81.78 \pm 0.14 \mathrm{a}$ & $24.42 \pm$ & $9.45 \pm 0.30 \mathrm{c}$ & $10.08 \pm 0.10 \mathrm{c}$ \\
\hline \multicolumn{7}{|c|}{ Treatment of interaction } \\
\hline & $358.43 \pm 13.05 \mathrm{a}$ & $179.85 \pm 2.52 b$ & & & $10.73 \pm 0.17 \mathrm{a}$ & $10.43 \pm 0.36 \mathrm{c}$ \\
\hline & $360.19 \pm 1$ & $181.42 \pm$ & $.80 \mathrm{~b}$ & $=0.16 \mathrm{a}$ & $11.03 \pm 0.42 \mathrm{a}$ & $11.62 \pm 0.17 \mathrm{a}$ \\
\hline N3D1 & $323.71 \pm 9.95 b$ & $185.98 \pm 2.92 \mathrm{a}$ & $75.88 \pm 0.18 \mathrm{a}$ & $24.35 \pm 0.38 \mathrm{~b}$ & $10.52 \pm 0.22 \mathrm{a}$ & $11.07 \pm 0.20 \mathrm{~b}$ \\
\hline & $367.95 \pm 26.13 \mathrm{ab}$ & $172.82 \pm 4.35 b$ & $77.19 \pm 0.78 \mathrm{c}$ & $24.23 \pm 0.14 \mathrm{a}$ & $11.10 \pm 0.88 \mathrm{~b}$ & $12.00 \pm 0.08 \mathrm{ab}$ \\
\hline & $390.14 \pm 17.00 \mathrm{a}$ & $178.17 \pm 3.00 \mathrm{a}$ & $78.08 \pm 0.26 b$ & $24.32 \pm 0.23 \mathrm{a}$ & $12.01 \pm 0.37 \mathrm{a}$ & $12.26 \pm 0.15 \mathrm{a}$ \\
\hline N2D1 & $358.00 \pm 26.38 \mathrm{~b}$ & $176.55 \pm 2.11 \mathrm{a}$ & $80.73 \pm 0.29 a$ & $24.27 \pm 0.10 \mathrm{a}$ & $11.37 \pm 0.43 \mathrm{ab}$ & $11.76 \pm 0.11 \mathrm{~b}$ \\
\hline N1D3 & $323.86 \pm 10.29 \mathrm{a}$ & $167.93 \pm 1.99 b$ & $79.92 \pm 0.14 \mathrm{c}$ & $24.28 \pm 0.05 b$ & $10.70 \pm 0.52 b$ & $10.66 \pm 0.37 b$ \\
\hline & $316.50 \pm 6.50 \mathrm{ab}$ & $168.31 \pm 0.49 b$ & $81.05 \pm 0.22 b$ & $24.62 \pm 0.23 \mathrm{a}$ & $12.23 \pm 0.51 \mathrm{a}$ & $11.50 \pm 0.35 \mathrm{a}$ \\
\hline N1D1 & $290.93 \pm 19.27 b$ & $176.32 \pm 5.01 \mathrm{a}$ & $83.63 \pm 0.36 \mathrm{a}$ & $24.55 \pm 0.07 \mathrm{a}$ & $9.45 \pm 0.39 c$ & $10.68 \pm 0.07 \mathrm{~b}$ \\
\hline N0D3 & $291.36 \pm 16.46 \mathrm{a}$ & $145.34 \pm 0.93 b$ & $83.06 \pm 0.33 c$ & $24.59 \pm 0.19 b$ & $7.48 \pm 0.75 \mathrm{a}$ & $8.27 \pm 0.20 \mathrm{a}$ \\
\hline N0D2 & $258.14 \pm 15.03 b$ & $153.56 \pm 1.94 \mathrm{a}$ & $84.03 \pm 0.39 b$ & $24.47 \pm 0.06 \mathrm{~b}$ & $6.69 \pm 0.35 \mathrm{ab}$ & $7.42 \pm 0.08 b$ \\
\hline N0D1 & $230.51 \pm 1.75 b$ & $153.86 \pm 3.06 \mathrm{a}$ & $86.89 \pm 0.11 \mathrm{a}$ & $25.03 \pm 0.09 \mathrm{a}$ & $6.46 \pm 0.46 \mathrm{~b}$ & $6.80 \pm 0.05 c$ \\
\hline
\end{tabular}

Different letters $(a, b, c)$ indicate significant differences among different seeding rates under a given $\mathrm{N}$ application rate (LSD's multiple range tests, $\mathrm{p}<0.05)$. Four nitrogen application rates $\left(\mathrm{N} 0,0 \mathrm{kgha}^{-1} ; \mathrm{N} 1\right.$, $\left.150 \mathrm{kgha}^{-1} ; \mathrm{N} 2,190 \mathrm{kgha}^{-1} ; \mathrm{N} 3,240 \mathrm{kgha}^{-1}\right)$ and three seeding rates (D1, $22.22 \mathrm{kgha}^{-1} ; \mathrm{D} 2,25.00 \mathrm{kgha}^{-1}$; D3, $28.57 \mathrm{kgha}^{-1}$ ) were tested. The yield components are shown as the mean values of two years' data

As the rate of $\mathrm{N}$ application increased, the effective panicle number, spikelet number per panicle, and 1000-grain weight of conventional rice increased, whereas the seed setting rate decreased. The effective panicle number, spikelet number per panicle, and 1000-grain weight were significantly higher in the $\mathrm{N} 3$ treatment than in the $\mathrm{N} 2, \mathrm{~N} 1$, and N0 treatments by $5.31-33.63 \%, 3.83-18.88 \%$, and $0.31-1.59 \%$, respectively. However, the seed setting rate was significantly lower in the N3 treatment than in the N0-2 treatments by $1.59-6.02 \%$. As the rate of seeding increased, the effective panicle number and 1000-grain weight of conventional rice increased, whereas the seed setting rate and spikelet number per panicle decreased. Compared with other $\mathrm{N}$ application and seeding rate combinations, the better yield performance of the N3D3 treatment may have been due to its high 1000-grain weight and the consistent responses of the other yield components. 


$$
-673 \text { - }
$$

Table 3. Conventional rice yield and yield components under different $N$ fertilizer application rates and seeding rates

\begin{tabular}{|c|c|c|c|c|c|c|}
\hline \multirow{2}{*}{ Treatment } & \multirow{2}{*}{\begin{tabular}{|c|}
$\begin{array}{c}\text { Number of } \\
\text { effective panicles } \\
\left(10^{4} \mathrm{ha}^{-1}\right)\end{array}$ \\
\end{tabular}} & \multirow{2}{*}{$\begin{array}{l}\text { Number of } \\
\text { spikelets per } \\
\text { panicle } \\
\end{array}$} & \multirow{2}{*}{$\begin{array}{l}\text { Seed setting } \\
\text { rate }(\%)\end{array}$} & \multirow{2}{*}{$\begin{array}{l}\text { 1000-grain } \\
\text { weight (g) }\end{array}$} & \multicolumn{2}{|c|}{ Grain yield $\left(\mathrm{kg} \mathrm{ha}^{-1}\right)$} \\
\hline & & & & & 2018 & 2019 \\
\hline \multicolumn{7}{|c|}{ Treatment of $\mathrm{N}$ application rate } \\
\hline N3 & $388.94 \pm 10.94 a$ & $167.59 \pm 2.50 \mathrm{a}$ & $81.75 \pm 0.10 \mathrm{~d}$ & $22.33 \pm 0.07 \mathrm{a}$ & $10.12 \pm 0.26 \mathrm{a}$ & $9.82 \pm 0.06 \mathrm{a}$ \\
\hline $\mathrm{N} 2$ & $369.34 \pm 18.61 b$ & $161.41 \pm 0.95 b$ & $85.18 \pm 0.27 \mathrm{c}$ & $22.26 \pm 0.18 \mathrm{ab}$ & $9.21 \pm 0.34 b$ & $9.35 \pm 0.07 \mathrm{~b}$ \\
\hline N1 & $334.66 \pm 3.03 \mathrm{c}$ & $155.12 \pm 0.82 \mathrm{c}$ & & $22.15 \pm 0.09 \mathrm{ab}$ & $9.17 \pm 0.25 b$ & $9.29 \pm 0.02 b$ \\
\hline No & $291.06 \pm 7.63 \mathrm{~d}$ & $140.98 \pm 0.86 \mathrm{~d}$ & $87.77 \pm 0.48 \mathrm{a}$ & $21.98 \pm 0.25 b$ & $5.59 \pm 0.27 \mathrm{c}$ & $6.49 \pm 0.07 \mathrm{c}$ \\
\hline \multicolumn{7}{|c|}{ Treatment of density } \\
\hline D3 & $349.83 \pm 2.67 \mathrm{a}$ & $153.26 \pm 0.43 c$ & & & $8.85 \pm 0.34 \mathrm{a}$ & $8.99 \pm 0.06 a$ \\
\hline D2 & $344.26 \pm 8.97 \mathrm{a}$ & $156.78 \pm 0.89 b$ & & $08 \mathrm{a}$ & $8.47 \pm 0.10 \mathrm{ab}$ & $8.63 \pm 0.14 b$ \\
\hline D1 & $343.91 \pm 15.44 \mathrm{a}$ & $158.78 \pm 1.61 \mathrm{a}$ & $86.58 \pm 0.21 \mathrm{a}$ & 21. & $8.25 \pm 0.54 b$ & $8.59 \pm 0.12 b$ \\
\hline \multicolumn{7}{|c|}{ Treatment of interaction } \\
\hline N3D3 & $365.52 \pm 13.36 b$ & $163.62 \pm 4.23 \mathrm{c}$ & $80.58 \pm 0.86 b$ & 23.0 & $9.86 \pm 0.54 b$ & $10.02=$ \\
\hline N3D2 & $391.84 \pm 19.45 \mathrm{a}$ & $167.40 \pm 2.37 \mathrm{~b}$ & $80.96 \pm 0.92 b$ & $21.98 \pm 0.06 \mathrm{~b}$ & $10.81 \pm 0.53 a$ & $9.66 \pm 0.13 \mathrm{a}$ \\
\hline N3D1 & $409.47 \pm 14.98 \mathrm{a}$ & $171.74 \pm 0.98 \mathrm{a}$ & & & $9.71 \pm 0.66 \mathrm{~b}$ & $9.77 \pm 0.07 \mathrm{a}$ \\
\hline N2D3 & $393.47 \pm 16.38 \mathrm{a}$ & $158.27 \pm 1.01 \mathrm{~b}$ & $83.53 \pm 0.65 b$ & $21.56 \pm$ & $9.68 \pm 0.59 a$ & $9.64 \pm 0.22 \mathrm{a}$ \\
\hline $\mathrm{N} 2 \mathrm{D} 2$ & $359.39 \pm 27.17 b$ & $161.81 \pm 1.69 \mathrm{a}$ & $85.82 \pm 0.80 \mathrm{a}$ & $22.55 \pm 0.19 \mathrm{a}$ & $9.13 \pm 0.70 \mathrm{ab}$ & $9.22 \pm 0.46 \mathrm{ab}$ \\
\hline $\mathrm{N} 2 \mathrm{D} 1$ & $355.15 \pm 12.49 \mathrm{~b}$ & $164.15 \pm 3.56 \mathrm{a}$ & $86.18 \pm 1.01 \mathrm{a}$ & $22.27 \pm 0.07 \mathrm{ab}$ & $8.83 \pm 0.36 b$ & $9.19 \pm 0.56 b$ \\
\hline N1D3 & $345.18 \pm 11.09 \mathrm{a}$ & $152.63 \pm 1.00 \mathrm{~b}$ & $85.28 \pm 0.53 b$ & $22.13 \pm 0.10 \mathrm{a}$ & $9.72 \pm 0.13 \mathrm{a}$ & $9.56 \pm 0.12 \mathrm{a}$ \\
\hline N1D2 & $340.78 \pm 2.76 \mathrm{ab}$ & $154.63 \pm 1.73 \mathrm{ab}$ & $86.87 \pm 0.17 \mathrm{ab}$ & $22.49 \pm 0.30 \mathrm{a}$ & $8.58 \pm 0.51 b$ & $9.23 \pm 0.15 \mathrm{a}$ \\
\hline N1D1 & $318.00 \pm 21.36 \mathrm{~b}$ & $158.09 \pm 0.49 \mathrm{a}$ & $87.39 \pm 0.54 \mathrm{a}$ & $21.99 \pm 0.09 \mathrm{a}$ & $9.21 \pm 0.62 \mathrm{ab}$ & $9.07 \pm 0.06 \mathrm{a}$ \\
\hline N0D3 & $295.16 \pm 15.39 \mathrm{a}$ & $138.53 \pm 2.24 b$ & $85.95 \pm 2.34 b$ & $22.07 \pm 0.75 \mathrm{a}$ & $6.15 \pm 0.36 \mathrm{a}$ & $6.73 \pm 0.27 a$ \\
\hline N0D2 & $285.03 \pm 12.45 \mathrm{a}$ & $143.26 \pm 2.07 \mathrm{a}$ & $88.34 \pm 0.69 \mathrm{a}$ & $21.53 \pm 0.53 b$ & $5.35 \pm 0.44 \mathrm{a}$ & $6.41 \pm 0.15 \mathrm{a}$ \\
\hline N0D1 & $293.00 \pm 14.07 \mathrm{a}$ & $141.15 \pm 3.16 \mathrm{ab}$ & $89.02 \pm 0.54 \mathrm{a}$ & $21.55 \pm 0.08 \mathrm{~b}$ & $5.27 \pm 0.69 \mathrm{a}$ & $6.33 \pm 0.21 \mathrm{a}$ \\
\hline
\end{tabular}

Different letters $(a, b, c)$ indicate significant differences among different seeding rates under a given $\mathrm{N}$ application rate (LSD's multiple range tests, $\mathrm{p}<0.05)$. Four nitrogen application rates $\left(\mathrm{N} 0,0 \mathrm{~kg} \mathrm{ha}^{-1}\right.$; N1, $\left.150 \mathrm{~kg} \mathrm{ha}^{-1} ; \mathrm{N} 2,190 \mathrm{~kg} \mathrm{ha}^{-1} ; \mathrm{N} 3,240 \mathrm{~kg} \mathrm{ha}^{-1}\right)$ and three seeding rates (D1, $22.22 \mathrm{~kg} \mathrm{ha}^{-1} ; \mathrm{D} 2,25.00 \mathrm{~kg}$ $\mathrm{ha}^{-1}$; D3, $28.57 \mathrm{~kg} \mathrm{ha}^{-1}$ ) were tested. The yield components are shown as the mean values of two years' data

\section{Effect of $N$ fertilizer application rate and seeding rates on growth characteristics of hybrid rice}

Growth characteristics of hybrid rice under each treatment are shown in Table 4. As the $\mathrm{N}$ application rate increased, the SPAD value, LAI, and dry matter accumulation of hybrid rice initially increased and then decreased, whereas the plant height continued to increase. There were no significant differences in the number of tillers under the N1, N2, and N3 treatments. The SPAD value, LAI, and dry matter accumulation were significantly higher in the $\mathrm{N} 2$ treatment than in the $\mathrm{N} 3, \mathrm{~N} 1$, and $\mathrm{N} 0$ treatments by $2.64-10.96 \%, 2.61-165.82 \%$, and $17.67-64.48 \%$, respectively. Plant height was significantly higher in the $\mathrm{N} 3$ treatment than in the $\mathrm{N} 2, \mathrm{~N} 1$, and $\mathrm{N} 0$ treatments by $1.30-26.89 \%$. All the growth indices of the D1 treatment were lower than those of the D2 and D3 treatments, and the plant height and LAI of D1 differed significantly from those of D2 and D3. The dry matter accumulation, SPAD value, number of tillers, and plant height were higher in the D2 treatment than in the D3 treatment, and the SPAD value of D2 was significantly higher than that of $\mathrm{D} 3$ by $0.85 \%$. The SPAD value, LAI, dry matter accumulation, and the number of tillers were higher in the N2D2 treatment than in other $\mathrm{N}$ application and seeding rate combinations. 
Table 4. Growth characteristics of hybrid rice under different $N$ fertilizer application rates and seeding rates

\begin{tabular}{c|c|c|c|c|c}
\hline Treatment & SPAD & LAI & $\begin{array}{c}\text { Dry matter accumulation } \\
\left(10^{3} \mathrm{~kg} \mathrm{ha}^{-1}\right)\end{array}$ & $\begin{array}{c}\text { Number of tillers } \\
\left(10^{4} \mathrm{ha}^{-1}\right)\end{array}$ & $\begin{array}{c}\text { Plant height } \\
(\mathrm{cm})\end{array}$ \\
\hline \multicolumn{7}{c}{ Treatment of N application rate } \\
\hline N3 & $43.19 \pm 0.19 \mathrm{~b}$ & $6.14 \pm 0.12 \mathrm{~b}$ & $11.09 \pm 0.40 \mathrm{~b}$ & $530.89 \pm 12.90 \mathrm{a}$ & $127.55 \pm 0.69 \mathrm{a}$ \\
N2 & $44.33 \pm 0.55 \mathrm{a}$ & $6.30 \pm 0.12 \mathrm{a}$ & $13.52 \pm 0.75 \mathrm{a}$ & $552.00 \pm 28.76 \mathrm{a}$ & $125.91 \pm 0.32 \mathrm{~b}$ \\
N1 & $42.21 \pm 0.42 \mathrm{c}$ & $4.30 \pm 0.13 \mathrm{c}$ & $11.49 \pm 0.38 \mathrm{~b}$ & $550.44 \pm 14.38 \mathrm{a}$ & $119.60 \pm 0.35 \mathrm{c}$ \\
N0 & $39.95 \pm 0.30 \mathrm{~d}$ & $2.37 \pm 0.11 \mathrm{~d}$ & $8.22 \pm 0.52 \mathrm{c}$ & $469.56 \pm 29.10 \mathrm{~b}$ & $100.52 \pm 0.40 \mathrm{~d}$ \\
\hline \multicolumn{7}{|c|}{ Treatment of density } \\
\hline \multicolumn{7}{c|}{ D3 } & $42.35 \pm 0.30 \mathrm{~b}$ & $4.88 \pm 0.09 \mathrm{a}$ & $11.01 \pm 0.31 \mathrm{a}$ & $523.17 \pm 25.72 \mathrm{ab}$ & $117.52 \pm 0.34 \mathrm{~b}$ \\
D2 & $42.71 \pm 0.31 \mathrm{a}$ & $4.82 \pm 0.09 \mathrm{a}$ & $11.34 \pm 0.33 \mathrm{a}$ & $545.50 \pm 16.73 \mathrm{a}$ & $118.24 \pm 0.81 \mathrm{~b}$ \\
D1 & $42.21 \pm 0.23 \mathrm{~b}$ & $4.63 \pm 0.17 \mathrm{~b}$ & $10.89 \pm 0.23 \mathrm{a}$ & $508.50 \pm 23.30 \mathrm{~b}$ & $119.43 \pm 0.37 \mathrm{a}$ \\
\hline \multicolumn{7}{|c|}{ Treatment of interaction } \\
\hline N3D3 & $43.06 \pm 0.56 \mathrm{a}$ & $6.01 \pm 0.10 \mathrm{~b}$ & $12.04 \pm 0.55 \mathrm{a}$ & $522.67 \pm 28.02 \mathrm{a}$ & $126.78 \pm 1.27 \mathrm{~b}$ \\
N3D2 & $43.06 \pm 0.51 \mathrm{a}$ & $6.18 \pm 0.15 \mathrm{a}$ & $10.87 \pm 0.71 \mathrm{~b}$ & $537.33 \pm 17.47 \mathrm{a}$ & $126.32 \pm 2.18 \mathrm{~b}$ \\
N3D1 & $43.46 \pm 0.78 \mathrm{a}$ & $6.24 \pm 0.11 \mathrm{a}$ & $10.37 \pm 0.54 \mathrm{~b}$ & $532.67 \pm 23.18 \mathrm{a}$ & $129.56 \pm 1.62 \mathrm{a}$ \\
\hline N2D3 & $43.99 \pm 0.56 \mathrm{~b}$ & $6.31 \pm 0.06 \mathrm{~b}$ & $13.42 \pm 0.78 \mathrm{ab}$ & $545.33 \pm 40.86 \mathrm{ab}$ & $125.24 \pm 1.31 \mathrm{~b}$ \\
N2D2 & $45.15 \pm 0.72 \mathrm{a}$ & $6.56 \pm 0.10 \mathrm{a}$ & $14.16 \pm 0.99 \mathrm{a}$ & $597.33 \pm 45.00 \mathrm{a}$ & $126.96 \pm 0.73 \mathrm{a}$ \\
N2D1 & $43.86 \pm 0.75 \mathrm{~b}$ & $6.02 \pm 0.25 \mathrm{c}$ & $12.99 \pm 0.60 \mathrm{~b}$ & $513.33 \pm 12.22 \mathrm{~b}$ & $125.52 \pm 0.99 \mathrm{ab}$ \\
\hline N1D3 & $42.52 \pm 0.62 \mathrm{a}$ & $4.75 \pm 0.16 \mathrm{a}$ & $10.83 \pm 1.84 \mathrm{a}$ & $580.67 \pm 27.30 \mathrm{a}$ & $118.28 \pm 0.76 \mathrm{~b}$ \\
N1D2 & $42.69 \pm 0.50 \mathrm{a}$ & $4.06 \pm 0.13 \mathrm{~b}$ & $11.79 \pm 0.23 \mathrm{a}$ & $586.00 \pm 42.00 \mathrm{a}$ & $121.28 \pm 0.64 \mathrm{a}$ \\
N1D1 & $41.43 \pm 0.23 \mathrm{~b}$ & $4.07 \pm 0.13 \mathrm{~b}$ & $11.85 \pm 1.04 \mathrm{a}$ & $484.67 \pm 28.59 \mathrm{~b}$ & $119.24 \pm 0.52 \mathrm{~b}$ \\
\hline N0D3 & $39.83 \pm 0.36 \mathrm{a}$ & $2.43 \pm 0.08 \mathrm{a}$ & $7.77 \pm 0.75 \mathrm{a}$ & $444.00 \pm 38.16 \mathrm{a}$ & $99.76 \pm 0.46 \mathrm{~b}$ \\
N0D2 & $39.95 \pm 0.36 \mathrm{a}$ & $2.48 \pm 0.06 \mathrm{a}$ & $8.52 \pm 0.72 \mathrm{a}$ & $461.33 \pm 27.59 \mathrm{a}$ & $98.40 \pm 1.36 \mathrm{~b}$ \\
N0D1 & $40.09 \pm 0.52 \mathrm{a}$ & $2.19 \pm 0.21 \mathrm{~b}$ & $8.36 \pm 0.25 \mathrm{a}$ & $503.33 \pm 75.80 \mathrm{a}$ & $103.40 \pm 1.12 \mathrm{a}$ \\
\hline
\end{tabular}

Different letters $(a, b, c)$ indicate significant differences among different seeding rates under a given $\mathrm{N}$ application rate (LSD's multiple range tests, $\mathrm{p}<0.05)$. Four nitrogen application rates $\left(\mathrm{N} 0,0 \mathrm{~kg} \mathrm{ha}^{-1}\right.$; N1, $\left.150 \mathrm{~kg} \mathrm{ha}^{-1} ; \mathrm{N} 2,190 \mathrm{~kg} \mathrm{ha}^{-1} ; \mathrm{N} 3,240 \mathrm{~kg} \mathrm{ha}^{-1}\right)$ and three seeding rates (D1, $22.22 \mathrm{~kg} \mathrm{ha}^{-1} ; \mathrm{D} 2,25.00 \mathrm{~kg}$ $\mathrm{ha}^{-1}$; D3, $28.57 \mathrm{~kg} \mathrm{ha}^{-1}$ ) were tested. The indicators in the table are the average of two years

\section{Effect of $N$ fertilizer application rate and seeding rates on growth characteristics of conventional rice}

Growth characteristics of conventional rice under each treatment are shown in Table 5. The SPAD value, LAI, and plant height increased as the rate of $\mathrm{N}$ application increased. There were no significant differences in the number of tillers or dry matter accumulation among the N1, N2, and N3 treatments. The SPAD value, LAI, and plant height were significantly higher in the $\mathrm{N} 3$ treatment than in the $\mathrm{N} 2, \mathrm{~N} 1$, and N0 treatments by $2.87-11.63 \%, 22.13-162.33 \%$, and $5.12-19.61 \%$, respectively. The dry matter accumulation was significantly higher in the D3 treatment than in the D2 and D1 treatments by $7.87 \%$ and $10.51 \%$; the LAI was significantly higher in D3 than in D2 and D1 by $4.61 \%$ and $7.58 \%$; and the number of tillers was significantly lower in D3 than in D2 by $5.46 \%$. There were no significant differences in the SPAD value among D1, D2, and D3. The plant height of D1 was higher than that of D2 and D3 by 1.43 and $1.15 \%$, respectively. The LAI of the N3D3 treatment was higher than other $\mathrm{N}$ application and seeding rate combinations, and the various growth traits of the N3D3 treatment were consistent with this result. 
Table 5. Growth characteristics of conventional rice under different $N$ fertilizer application rates and seeding rates

\begin{tabular}{c|c|c|c|c|c}
\hline Treatment & SPAD & LAI & $\begin{array}{c}\text { Dry matter accumulation } \\
\left(10^{3} \mathrm{~kg} \mathrm{ha}^{-1}\right)\end{array}$ & $\begin{array}{c}\text { Number of tillers } \\
\left(10^{4} \mathrm{ha}^{-1}\right)\end{array}$ & $\begin{array}{c}\text { Plant height } \\
(\mathrm{cm})\end{array}$ \\
\hline \multicolumn{7}{c}{ Treatment of N application rate } \\
\hline N3 & $44.06 \pm 0.28 \mathrm{a}$ & $5.85 \pm 0.06 \mathrm{a}$ & $11.33 \pm 0.34 \mathrm{a}$ & $532.89 \pm 32.53 \mathrm{a}$ & $113.43 \pm 1.13 \mathrm{a}$ \\
N2 & $42.83 \pm 0.26 \mathrm{~b}$ & $4.79 \pm 0.18 \mathrm{~b}$ & $10.75 \pm 0.54 \mathrm{a}$ & $500.22 \pm 23.48 \mathrm{ab}$ & $107.91 \pm 0.69 \mathrm{~b}$ \\
N1 & $42.70 \pm 0.30 \mathrm{~b}$ & $4.59 \pm 0.12 \mathrm{c}$ & $10.15 \pm 1.05 \mathrm{a}$ & $524.00 \pm 26.26 \mathrm{a}$ & $107.22 \pm 0.97 \mathrm{~b}$ \\
N0 & $39.47 \pm 0.23 \mathrm{c}$ & $2.23 \pm 0.09 \mathrm{~d}$ & $8.67 \pm 0.18 \mathrm{~b}$ & $466.44 \pm 28.71 \mathrm{~b}$ & $94.83 \pm 1.04 \mathrm{c}$ \\
\hline \multicolumn{7}{|c}{ Treatment of density } \\
\hline \multicolumn{7}{c|}{ D3 } & $42.20 \pm 0.25 \mathrm{a}$ & $4.54 \pm 0.10 \mathrm{a}$ & $10.83 \pm 0.32 \mathrm{a}$ & $496.17 \pm 17.56 \mathrm{~b}$ & $105.54 \pm 1.39 \mathrm{ab}$ \\
D2 & $42.27 \pm 0.36 \mathrm{a}$ & $4.34 \pm 0.08 \mathrm{~b}$ & $10.04 \pm 0.23 \mathrm{~b}$ & $524.83 \pm 24.32 \mathrm{a}$ & $105.25 \pm 1.24 \mathrm{~b}$ \\
D1 & $42.32 \pm 0.13 \mathrm{a}$ & $4.22 \pm 0.16 \mathrm{c}$ & $9.80 \pm 0.36 \mathrm{~b}$ & $496.67 \pm 25.32 \mathrm{~b}$ & $106.75 \pm 0.56 \mathrm{a}$ \\
\hline \multicolumn{7}{|c|}{ Treatment of interaction } \\
\hline N3D3 & $44.04 \pm 0.80 \mathrm{a}$ & $6.06 \pm 0.05 \mathrm{a}$ & $11.92 \pm 0.92 \mathrm{a}$ & $500.67 \pm 26.63 \mathrm{~b}$ & $111.98 \pm 1.64 \mathrm{~b}$ \\
N3D2 & $43.98 \pm 0.42 \mathrm{a}$ & $6.03 \pm 0.10 \mathrm{a}$ & $11.47 \pm 0.85 \mathrm{a}$ & $575.33 \pm 56.72 \mathrm{a}$ & $113.10 \pm 2.75 \mathrm{ab}$ \\
N3D1 & $44.17 \pm 0.52 \mathrm{a}$ & $5.46 \pm 0.03 \mathrm{~b}$ & $10.59 \pm 0.81 \mathrm{~b}$ & $522.67 \pm 30.02 \mathrm{~b}$ & $115.20 \pm 2.32 \mathrm{a}$ \\
\hline N2D3 & $42.65 \pm 0.33 \mathrm{a}$ & $5.28 \pm 0.21 \mathrm{a}$ & $12.16 \pm 0.69 \mathrm{a}$ & $478.67 \pm 23.18 \mathrm{~b}$ & $105.30 \pm 0.65 \mathrm{~b}$ \\
N2D2 & $43.07 \pm 0.83 \mathrm{a}$ & $4.54 \pm 0.02 \mathrm{~b}$ & $8.90 \pm 0.51 \mathrm{~b}$ & $540.67 \pm 26.03 \mathrm{a}$ & $106.60 \pm 1.31 \mathrm{~b}$ \\
N2D1 & $42.75 \pm 0.57 \mathrm{a}$ & $4.54 \pm 0.34 \mathrm{~b}$ & $9.39 \pm 1.21 \mathrm{~b}$ & $481.33 \pm 24.19 \mathrm{~b}$ & $111.84 \pm 1.87 \mathrm{a}$ \\
\hline N1D3 & $42.60 \pm 0.62 \mathrm{a}$ & $4.56 \pm 0.04 \mathrm{a}$ & $10.63 \pm 0.78 \mathrm{a}$ & $533.33 \pm 31.64 \mathrm{a}$ & $106.28 \pm 2.33 \mathrm{a}$ \\
N1D2 & $42.60 \pm 0.49 \mathrm{a}$ & $4.55 \pm 0.12 \mathrm{a}$ & $11.13 \pm 0.99 \mathrm{a}$ & $522.67 \pm 37.17 \mathrm{a}$ & $107.44 \pm 1.07 \mathrm{a}$ \\
N1D1 & $42.90 \pm 0.63 \mathrm{a}$ & $4.66 \pm 0.24 \mathrm{a}$ & $10.48 \pm 1.43 \mathrm{a}$ & $516.00 \pm 37.47 \mathrm{a}$ & $107.94 \pm 1.16 \mathrm{a}$ \\
\hline N0D3 & $39.51 \pm 0.21 \mathrm{a}$ & $2.25 \pm 0.11 \mathrm{a}$ & $8.60 \pm 0.35 \mathrm{a}$ & $472.00 \pm 41.62 \mathrm{a}$ & $98.60 \pm 2.87 \mathrm{a}$ \\
N0D2 & $39.43 \pm 0.67 \mathrm{a}$ & $2.22 \pm 0.10 \mathrm{a}$ & $8.68 \pm 0.28 \mathrm{a}$ & $460.67 \pm 37.17 \mathrm{a}$ & $93.86 \pm 3.12 \mathrm{~b}$ \\
N0D1 & $39.47 \pm 0.59 \mathrm{a}$ & $2.22 \pm 0.07 \mathrm{a}$ & $8.72 \pm 0.27 \mathrm{a}$ & $466.67 \pm 60.58 \mathrm{a}$ & $92.02 \pm 0.83 \mathrm{~b}$ \\
\hline
\end{tabular}

Different letters $(a, b, c)$ indicate significant differences among different seeding rates under a given $\mathrm{N}$ application rate (LSD's multiple range tests, $\mathrm{p}<0.05)$. Four nitrogen application rates $\left(\mathrm{N} 0,0 \mathrm{~kg} \mathrm{ha}^{-1}\right.$; N1, $\left.150 \mathrm{~kg} \mathrm{ha}^{-1} ; \mathrm{N} 2,190 \mathrm{~kg} \mathrm{ha}^{-1} ; \mathrm{N} 3,240 \mathrm{~kg} \mathrm{ha}^{-1}\right)$ and three seeding rates (D1, $22.22 \mathrm{~kg} \mathrm{ha}^{-1} ; \mathrm{D} 2,25.00 \mathrm{~kg}$ $\mathrm{ha}^{-1}$; D3, $28.57 \mathrm{~kg} \mathrm{ha}^{-1}$ ) were tested. The indicators in the table are the average of two years

\section{Response of rice yield to different $N$ application rates and seeding rates}

We used regression simulation analysis to analyze the relationships between $\mathrm{N}$ application rate, sowing rate, and rice yield. The following binary quadratic equations were obtained:

Hybrid rice:

$$
\begin{gathered}
y_{1}=-40.3579+0.0691 \mathrm{n}+3.5676 \mathrm{~d}-1.1367 \times 10^{-4} n^{2}-0.0661 d^{2} \\
-1.0122 \times 10^{-3} n d
\end{gathered}
$$

Conventional rice:

$$
\begin{aligned}
y_{1}=9.1697+ & 0.0325 \mathrm{n}-0.3599 \mathrm{~d}-4.5817 \times 10^{-5} n^{2} \\
& +9.2691 \times 10^{-3} d^{2}-2.2258 \times 10^{-4} n d
\end{aligned}
$$

In these equations, $\mathrm{y}_{1}$ represents grain yield $\left(10^{3} \mathrm{~kg} \mathrm{ha}^{-1}\right)$, $\mathrm{n}$ represents the $\mathrm{N}$ application rate $\left(\mathrm{kg} \mathrm{ha}^{-1}\right)$, and $\mathrm{d}$ represents the seeding rate $\left(\mathrm{kg} \mathrm{ha}^{-1}\right)$. The $F$-tests of (Eq.3) and (Eq.4) were highly significant $(P<0.01)$, indicating that the equations accurately 
expressed the relationships between $\mathrm{N}$ rate, seeding rate, and yield of hybrid rice or conventional rice.

Figure 1 shows plots of (Eq.3) and (Eq.4); both are convex parabolic surfaces. According to (Eq.3), the yield of hybrid rice was predicted to reach a maximum when the $\mathrm{N}$ application rate and seeding rates were $190.32 \mathrm{~kg} \mathrm{ha}^{-1}$ and $25.54 \mathrm{~kg} \mathrm{ha}^{-1}$, respectively. According to (Eq.4), the yield of conventional rice was predicted to reach a maximum when the $\mathrm{N}$ application rate and seeding rates were $238.74 \mathrm{~kg} \mathrm{ha}^{-1}$ and $28.57 \mathrm{~kg} \mathrm{ha}^{-1}$, respectively. As shown in Figure 1, the grain yield of hybrid and conventional rice increased initially, then decreased as $\mathrm{N}$ fertilizer and seeding rates were increased. This result demonstrates that only the appropriate amounts of $\mathrm{N}$ application and seeding promote high yields; it also provides a theoretical basis for the optimization of $\mathrm{N}$ fertilizer and seeding rates.
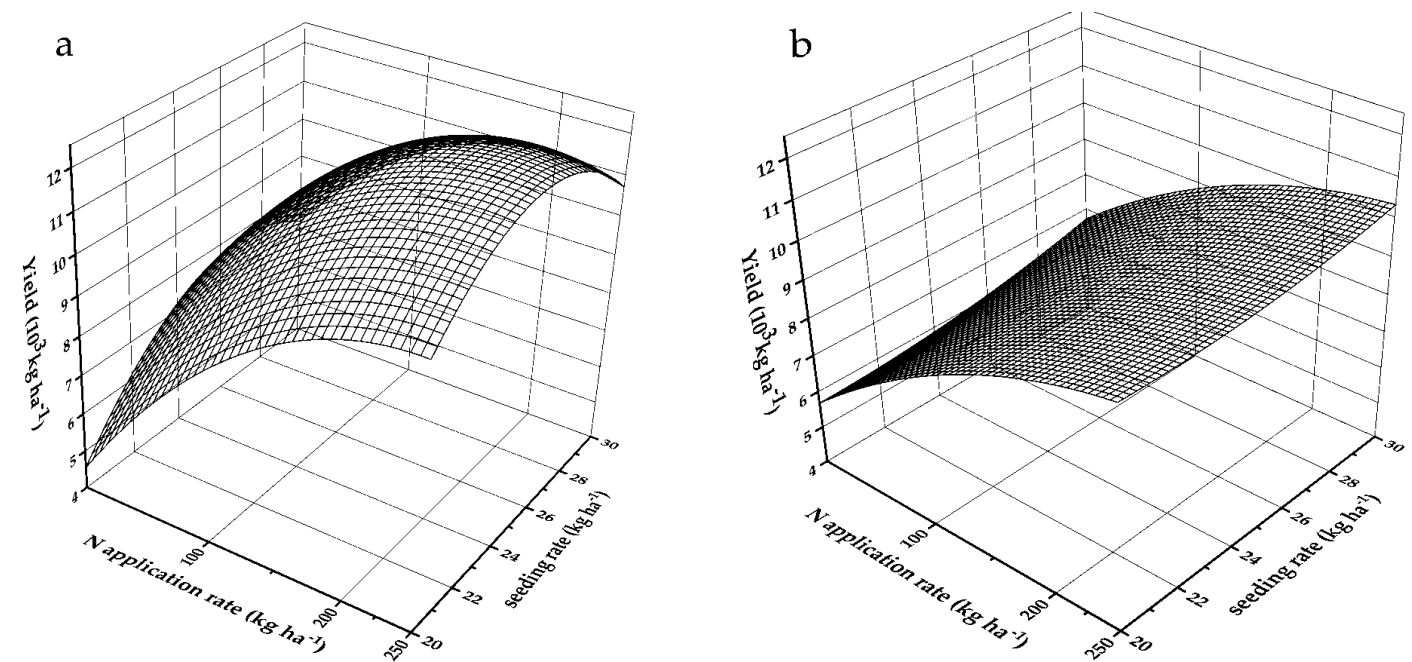

Figure 1. Relationship between rice yield, $N$ application rate, and seeding rate in (a) hybrid rice and (b) conventional rice. Yields are the average of two years

\section{The canonical correlation between growth traits and rice yield and its components}

The growth of rice plants affects yield formation. We therefore used canonical correlation analysis to explore the relationship between growth traits and yield and its components. As shown in Table 6, the correlation coefficients of canonical variables I, II, and III were relatively large $(0.9883,0.8803$, and 0.8201 , respectively) and highly significant $(P<0.01)$. However, the eigenvalues of canonical variables I and II accounted for $94.80 \%$ of the total, and canonical correlation analysis was therefore carried out for canonical variables I and II.

Table 6. Canonical correlation analysis of growth traits, yield and yield components

\begin{tabular}{c|c|c|c|c|c|c}
\hline No. & $\begin{array}{c}\text { Canonical } \\
\text { correlation } \\
\text { coefficient }\end{array}$ & Eigenvalues & Wilk's & $\begin{array}{c}\text { Chi-square } \\
\text { value }\end{array}$ & df & Sig. \\
\hline 1 & 0.9883 & 42.1413 & 0.0012 & 118.023 & 25 & 0.0001 \\
2 & 0.8803 & 3.4441 & 0.0508 & 52.1445 & 16 & 0.0001 \\
3 & 0.8201 & 2.0547 & 0.2258 & 26.042 & 9 & 0.002 \\
4 & 0.5512 & 0.4365 & 0.6897 & 6.5004 & 4 & 0.1648 \\
5 & 0.096 & 0.0093 & 0.9908 & 0.1621 & 1 & 0.6873 \\
\hline
\end{tabular}


Because the units of the original variables were inconsistent, we used standardized canonical coefficients in the analysis to give canonical correlation models $u$ and $v$. The correlation coefficient (canonical load factor) between the original variable and the canonical variable was also calculated. The calculation results are shown in Table 7, and the compositions of canonical variables I and II (Eq.5-8) are:

$$
\begin{aligned}
& u_{1}=0.2199 x_{1}-0.6085 x_{2}+0.0493 x_{3}-0.0604 x_{4}-0.6354 x_{5} \\
& v_{1}=-0.4005 y_{1}+0.0505 y_{2}-0.4867 y_{3}+0.2885 y_{4}+0.1809 y_{5} \\
& u_{2}=2.1927 x_{1}-0.9744 x_{2}+0.3605 x_{3}-0.2252 x_{4}-1.1354 x_{5} \\
& v_{2}=0.3592 y_{1}+1.0819 y_{2}-0.2952 y_{3}+0.9618 y_{4}+0.2311 y_{5}
\end{aligned}
$$

\begin{tabular}{|c|c|c|c|c|}
\hline \multirow{2}{*}{ Character(U) } & \multicolumn{2}{|c|}{ Canonical variable ( I ) } & \multicolumn{2}{|c|}{ Canonical variable (II ) } \\
\hline & $\mathrm{u}_{1}$ & $\mathrm{r}$ & $\mathrm{u}_{2}$ & $\mathrm{r}$ \\
\hline $\operatorname{SPAD}\left(\mathrm{x}_{1}\right)$ & 0.2199 & -0.8596 & 2.1927 & 0.5025 \\
\hline $\operatorname{LAI}\left(\mathrm{x}_{2}\right)$ & -0.6085 & -0.9294 & -0.9744 & 0.3144 \\
\hline $\begin{array}{c}\text { Dry matter accumulation } \\
\left(\mathrm{x}_{3}\right)\end{array}$ & 0.0493 & -0.7931 & 0.3605 & 0.3073 \\
\hline Number of tillers $(\mathrm{x} 4)$ & -0.0604 & -0.6913 & -0.2252 & 0.2003 \\
\hline Plant height $\left(\mathrm{x}_{5}\right)$ & -0.6354 & -0.9770 & -1.1354 & -0.1224 \\
\hline \multirow{2}{*}{ Character (V) } & \multicolumn{2}{|c|}{ Canonical variable ( I ) } & \multicolumn{2}{|c|}{ Canonical variable (II ) } \\
\hline & $\mathrm{v}_{1}$ & $\mathrm{r}$ & $\mathrm{v}_{2}$ & $r$ \\
\hline Grain yield $\left(\mathrm{y}_{1}\right)$ & -0.4005 & -0.9433 & 0.3592 & 0.1672 \\
\hline $\begin{array}{l}\text { Effective panicle number } \\
\left(\mathrm{y}_{2}\right)\end{array}$ & 0.0505 & -0.6481 & 1.0819 & 0.6786 \\
\hline $\begin{array}{l}\text { Spikelet number per } \\
\text { panicle }\left(\mathrm{y}_{3}\right)\end{array}$ & -0.4867 & -0.9616 & -0.2952 & -0.1044 \\
\hline Seed setting rate $\left(\mathrm{y}_{4}\right)$ & 0.2885 & 0.8721 & 0.9618 & 0.3338 \\
\hline 1000-grain weight ( $\left.\mathrm{y}_{5}\right)$ & 0.1809 & -0.3574 & 0.2311 & -0.6327 \\
\hline
\end{tabular}

Table 7. Canonical variables and canonical load factors

For canonical variables $\mathrm{I}\left(\mathrm{u}_{1}, \mathrm{v}_{1}\right)$, the correlation coefficients between $\mathrm{u}_{1}$ and the SPAD value $\left(\mathrm{x}_{1}\right)$, LAI $\left(\mathrm{x}_{2}\right)$, and plant height $\left(\mathrm{x}_{5}\right)$ were relatively high $(-0.8596,-0.9294$, and -0.9770 , respectively). Therefore, $\mathrm{u}_{1}$ mainly described the comprehensive characteristics of the SPAD value, LAI, and plant height. As the SPAD value, LAI, and plant height decreased, $\mathrm{u} 1$ tended to increase. In the same way, $\mathrm{v}_{1}$ was negatively correlated with grain yield $\left(\mathrm{y}_{1}\right)$ and spikelet number per panicle $\left(\mathrm{y}_{3}\right)$ and positively correlated with seed setting rate $\left(\mathrm{y}_{4}\right)$. The associated correlation coefficients were $-0.9433,-0.9616$, and -0.8721 , respectively. Therefore, $\mathrm{v} 1$ mainly described the comprehensive characteristics of grain yield, spikelet number per panicle, and seed setting rate. As grain yield and spikelet number per panicle decreased and seed setting rate increased, v1 tended to increase. This linear combination showed that the SPAD value, LAI, and plant height were closely related to grain yield, spikelet number per panicle, and seed setting rate. The increase in the SPAD value, LAI, and plant height may have caused the increase in grain yield and spikelet number per panicle and the decrease in seed setting rate.

For canonical variables II $\left(\mathrm{u}_{2}, \mathrm{v}_{2}\right)$, the correlation coefficient between $\mathrm{u}_{2}$ and the SPAD value $\left(\mathrm{x}_{1}\right)$ was the highest $(0.5025)$. Therefore, $\mathrm{u}_{2}$ mainly described the characteristic of 
the SPAD value, and as the SPAD value increased, $\mathrm{u}_{2}$ also increased. In the same way, $\mathrm{v}_{2}$ had a positive correlation with effective panicle number $\left(\mathrm{y}_{2}\right)$ and a negative correlation with 1000-grain weight ( $\mathrm{y}_{5}$ ) with correlation coefficients of 0.6786 and -0.6327 , respectively. Therefore, $\mathrm{v}_{2}$ mainly described the comprehensive traits of effective panicle number and 1000-grain weight. As effective panicle number increased and 1000-grain weight decreased, $v_{2}$ tended to increase. This linear combination showed that the SPAD value was closely related to effective panicle number and 1000-grain weight. The increase in the SPAD value may have caused the increase in the number of effective panicles and the decrease in 1000-grain weight.

\section{The Gray correlation analysis between growth traits and grain yield}

We used the gray correlation analysis method to analyze the degree of influence of growth traits on the yield of direct seeded rice across different $\mathrm{N}$ application rates and sowing rates. As shown in Figure 2, the relative strength of the relationship between individual growth traits and yield was: plant height $\left(\mathrm{x}_{5}\right)>\operatorname{LAI}\left(\mathrm{x}_{2}\right)>\operatorname{SPAD}\left(\mathrm{x}_{1}\right)>$ dry matter accumulation $\left(\mathrm{x}_{3}\right)>$ the number of tillers $\left(\mathrm{x}_{4}\right)$. The correlations of yield with plant height and LAI were relatively high, indicating that these two traits had a greater impact on yield across different $\mathrm{N}$ application rates and sowing rates.

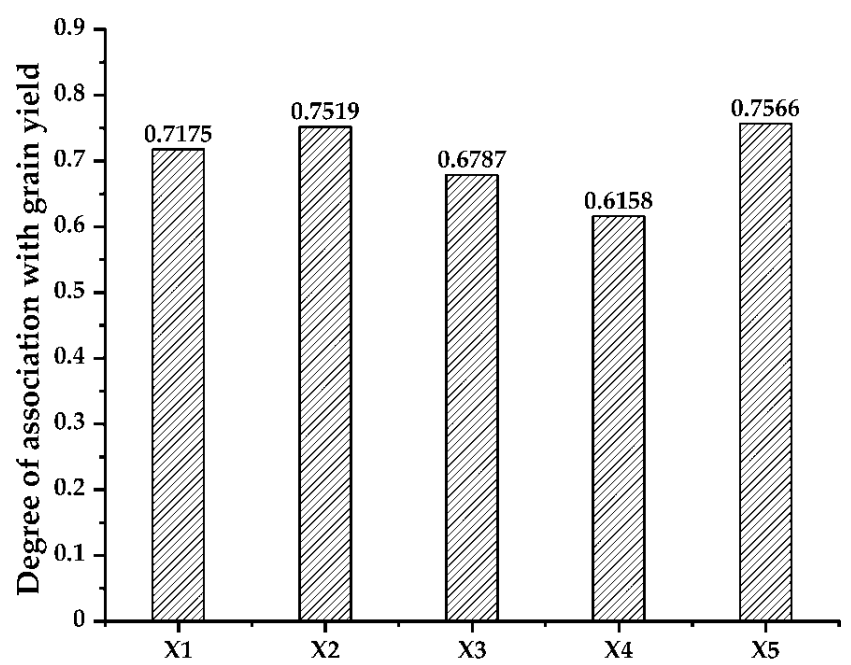

Figure 2. Degree of association between growth traits and grain yield. $x_{1}$ represents SPAD, $x_{2}$ represents LAI, $x_{3}$ represents dry matter accumulation, $x_{4}$ represents the number of tillers, and $x_{5}$ represents plant height

\section{Discussion}

Rice yield is regulated by genomic regions called quantitative trait loci and influenced by the external environment. Yield is one of the most important and complex agronomic traits (Wang et al., 2012; Zeng et al., 2017; Zhang et al., 2017). Chuma et al. (2020) showed that in high and middle altitude areas, when the $\mathrm{N}$ application rate exceeds $120 \mathrm{~kg} \mathrm{ha}^{-1}$, yield is reduced due to excessive tillers. Wang et al. (2014) suggested that a medium seeding density $(25 \mathrm{~cm} \times 17 \mathrm{~cm})$ of direct seeded rice is suitable for high-yield hybrid rice. In this study, the effective panicle number of hybrid rice was highest in the medium $\mathrm{N}$ and medium density (N2D2) treatment, which was conducive to the 
production of grain yield. Too high or too low $\mathrm{N}$ application rates and sowing rates caused the yield to decrease. A regression analysis predicted that an $\mathrm{N}$ application rate of $190.32 \mathrm{~kg} \mathrm{ha}^{-1}$ and a seeding rate of $25.54 \mathrm{~kg} \mathrm{ha}^{-1}$ would produce the highest yield of hybrid rice. The SPAD value, LAI, dry matter accumulation, and the number of tillers were higher in the N2D2 treatment than in any other rate combination. Conventional rice had the largest thousand-grain weight under high $\mathrm{N}$ application rate and high density (N3D3), which was conducive to the production of grain yield. A regression analysis predicted that an $\mathrm{N}$ application rate of $238.74 \mathrm{~kg} \mathrm{ha}^{-1}$ and a seeding rate of $28.57 \mathrm{~kg} \mathrm{ha}^{-1}$ would produce the highest grain yield of conventional rice. Grain yield of each treatment increased as $\mathrm{N}$ fertilizer rate and seeding rates were increased. There was no significant difference in grain yield between the N1 and N2 treatments in 2018 and 2019, but the grain yield of conventional rice increased significantly when the $\mathrm{N}$ application rate was increased to $240 \mathrm{~kg} \mathrm{ha}^{-1}$. The yield of conventional rice increased with an increase in seeding rate. LAI of the N3D3 treatment was highest compared with other N application and seeding rate combinations, and the various growth traits of the N3D3 treatment were more consistent. These results suggest that suitable $\mathrm{N}$ application rates and sowing rates of hybrid rice and conventional rice are quite different. Specifically, the optimal N application rate and sowing rate of conventional rice are higher than those of hybrid rice.

In rice, yield depends on indirect traits such as plant height, growth period, tillering ability, ear length, seed length, seed setting rate, and the number of grains per panicle, as well as direct traits such as unit area and/or the number of panicles per plant, filled grains per ear, and 1000-grain weight (Sakamoto and Matsuoka, 2008; Huang et al., 2013). Previous studies have shown that rice yield has a significant positive correlation with leaf area and dry weight (Li et al., 2019b). Some scholars believe that increasing plant height is an effective way to increase yield without lodging (Li et al., 2019a). The SPAD value is related to the $\mathrm{N}$ content of the plant, and the SPAD value of crop leaves can be used as a reference trait for adjusting grain yield (Swain and Sandip, 2010). In this study, a canonical correlation analysis of crop growth traits and yield traits showed that the SPAD value, LAI, and plant height were closely related to grain yield, spikelet number per panicle, and seed setting rate. The increase in the SPAD value, LAI, and plant height may have caused the increase in grain yield and spikelet number per panicle and the decrease in seed setting rate. Another linear combination showed that the SPAD value had a close relationship with effective panicle number and 1000-grain weight. The increase in the SPAD value may have caused the increase in the number of effective panicles and the decrease in 1000-grain weight. A Gray correlation analysis showed that plant height and leaf area index had the largest correlations with grain yield, indicating that they are essential indices that affect grain yield. In the follow-up research, if more hybrid and conventional rice varieties are used as materials, it will be more conducive to perfecting the research conclusions and guiding practical production.

\section{Conclusion}

The yield of direct seeded rice showed a downward parabolic trend as $\mathrm{N}$ application rate and sowing rate increased. Excessive $\mathrm{N}$ application and sowing rate were not conducive to the production of higher yield, but the optimal $\mathrm{N}$ application rate and sowing rate of conventional rice were higher than those of hybrid rice. 
Author Contributions. Lu, B. L. conceived and designed the research framework; Chen, Q. H. and Hao, R. Q. performed the experiments and analyzed the data; Tang, J. C. wrote the manuscript; Li, Z. X. revised the manuscript; Lu, B. L. supervised the work and finalized the manuscript. All authors read and approved the manuscript.

Funding. This work was supported by the National Key Research and Development Program of China (No. 2017YFD030140404).

\section{REFERENCES}

[1] Abid, M., Khan, I., Mahmood, F., Ashraf, U., Anjum, S. A. (2015): Response of Hybrid Rice to Various Transplanting Dates and Nitrogen Application Rates. - Philippine Agricultural Scientist 98(1): 98-104.

[2] Aleminew, A., Alemayehu, G., Adgo, E., Tadesse, T. (2020): Influence of nitrogen on the growth and use efficiency of rainfed lowland rice in northwest Ethiopia. - Journal of Plant Nutrition 43(15): 2243-2258.

[3] Aslam, M., Hussain, S., Nazir, M. S. (2002): Biological response of direct-seeded coarse rice to seeding density and planting time. - Pakistan Journal of Agricultural Sciences 39(1): 28-31.

[4] Chen, S., Cai, S., Chen, X., Zhang, G. (2009): Genotypic Differences in Growth and Physiological Responses to Transplanting and Direct Seeding Cultivation in Rice. - Rice Science 16(2): 143-150.

[5] Chuma, B. A., Cotter, M., Kalisa, A., Rajaona, A., Senthilkumar, K., Stuerz, S., Vincent, I., Asch, F. (2020): Altitude, temperature, and N Management effects on yield and yield components of contrasting lowland rice cultivars. - Journal of Agronomy and Crop Science 206(4): 456-465.

[6] Dofing, S. M., Knight, C. W. (1994): Yield Component Compensation in Uniculm Barley Lines. - Agronomy Journal 86(2): 273-276.

[7] Hardoon, D. R., Szedmak, S., Shawe-Taylor, J. (2004): Canonical Correlation Analysis: An Overview with Application to Learning Methods. - Neural computation 16(12): 26392664.

[8] Huang, R., Jiang, L., Zheng, J., Wang, T., Wang, H., Huang, Y., Hong, Z. (2013): Genetic bases of rice grain shape: so many genes, so little known. - Trends in plant science 18(4): 218-226.

[9] Kumar, V., Ladha, J. K. (2011): Direct Seeding of Rice. Recent Developments and Future Research Needs. - Advances in Agronomy 111: 297-413.

[10] Li, R., Li, M., Ashraf, U., Liu, S., Zhang, J. (2019a): Exploring the Relationships Between Yield and Yield-Related Traits for Rice Varieties Released in China from 1978 to 2017. Frontiers Plant Science 10: 543.

[11] Li, Y., Lai, R., Li, W., Liu, J., Huang, M., Tang, Y., Tang, X., Pan, S., Duan, M., Tian, H., Wu, L., Wang, S., Mo, Z. (2019b): $\gamma$-Aminobutyric Acid Regulates Grain Yield Formation in Different Fragrant Rice Genotypes Under Different Nitrogen Levels. - Journal of Plant Growth Regulation 39(2): 738-750.

[12] Li, B., Gong, L., Qu, H., Jin, D., Sun, W. (2020): Effects of Nitrogen Application Rate on Rice Growth and Yield in Liaohe Delta. - Crops 1: 173-178. (in Chinese with English abstract).

[13] Liang, X. Q., Li, H., Wang, S. X., Ye, Y. S., Ji, Y. J., Tian, G. M., van Kessel, C., Linquist, B. A. (2013): Nitrogen management to reduce yield-scaled global warming potential in rice. - Field Crops Research 146: 66-74.

[14] Liu, H., Hussain, S., Zheng, M., Peng, S., Huang, J., Cui, K., Nie, L. (2015): Dry directseeded rice as an alternative to transplanted-flooded rice in Central China. - Agronomy for Sustainable Development 35(1): 285-294. 
[15] Lui, S., Cao, H., Yang, H., Liu, S. (2014): The Correlation Analysis Between Tomato Yield, Growth Characters and Water and Nitrogen Supply. - Scientia Agricultura Sinica 47(22): 4445-4452. (in Chinese with English abstract).

[16] Peng, X., Liu, Y., Luo, S., Fan, L., Song, T., Guo, Y. (2007): Effects of Site-Specific Nitrogen Management on Yield and Dry Matter Accumulation of Rice from Cold Areas of Northeastern China. - Agricultural Sciences in China 6(6): 715-723.

[17] Peng, J., Zhang, K. (2010): Notice of Retraction: Research on linkage development between manufacturing and logistics industry of Yangtze Delta region - Based on gray correlation analysis. - International Conference on Computer and Communication Technologies in Agriculture Engineering, Chengdu.

[18] Rezaei, M., Vahed, H. S., Amiri, E., Motamed, M. K., Azarpour, E. (2009): The Effects of Irrigation and Nitrogen Management on Yield and Water Productivity of Rice. - World Applied Sciences Journal 7(2): 203-210.

[19] Rodríguez, M. C., Zientara-Rytter, K., Sirko, A. (2014): Nutrient Use Efficiency in Plants. - Springer International Publishing, Cham, Switzerland.

[20] Sakamoto, T., Matsuoka, M. (2008): Identifying and exploiting grain yield genes in rice. Current Opinion in Plant Biology 11(2): 209-214.

[21] Schnier, H. F., Dingkuhn, M., Datta, S. K. D., Mengel, K., Faronilo, J. E. (1990): Nitrogen Fertilization of Direct-Seeded Flooded vs. Transplanted Rice: I. Nitrogen Uptake, Photosynthesis, Growth, and Yield. - Crop Science 30(6): 1276.

[22] Swain, D. K., Sandip, S. J. (2010): Development of SPAD Values of Medium- and Longduration Rice Variety for Site-specific Nitrogen Management. - Journal of Agronomy 9(2): $38-44$.

[23] Tang, J., Sun, Z., Chen, Q., Damaris, R. N., Lu, B., Hu, Z. (2019): Nitrogen Fertilizer Induced Alterations in the Root Proteome of Two Rice Cultivars. - International journal of molecular sciences 20(15): 3674.

[24] Thapa, S., Thapa, K., Shrestha, J., Chaudhary, A. (2019): Effect of seedling age, seeding density and nitrogen fertilizer on growth and grain yield of rice (Oryza sativa L.). International Journal of Applied Biology 3(1): 81-87.

[25] Wang, S., Wu, K., Yuan, Q., Liu, X., Liu, Z., Lin, X., Zeng, R., Zhu, H., Dong, G., Qian, Q., Zhang, G., Fu, X. (2012): Control of grain size, shape and quality by OsSPL16 in rice. - Nature Genetics 44(8): 950-954.

[26] Wang, D. Y., Chen, S., Wang, Z., Ji, C. L., Xu, C. M., Zhang, X. F., Singh Chauhan, B. (2014): Optimizing Hill Seeding Density for High-Yielding Hybrid Rice in a Single Rice Cropping System in South China. - Plos One 9(10): e109417.

[27] Zeng, D., Tian, Z., Rao, Y., Dong, G., Yang, Y., Huang, L., Leng, Y., Xu, J., Sun, C., Zhang, G., Hu, J., Zhu, L., Gao, Z., Hu, X., Guo, L., Xiong, G., Wang, Y., Li, J., Qian, Q. (2017): Rational design of high-yield and superior-quality rice. - Nature Plants 3: 17031.

[28] Zhang, L., Yu, H., Ma, B., Liu, G., Wang, J., Wang, J., Gao, R., Li, J., Liu, J., Xu, J., Zhang, Y., Li, Q., Huang, X., Xu, J., Li, J., Qian, Q., Han, B., He, Z., Li, J. (2017): A natural tandem array alleviates epigenetic repression of IPA1 and leads to superior yielding rice.Nature Communications 8: 14789. 